\title{
John Cheever and the Management of Middlebrow Misery
}

\author{
Timothy Aubry
}

The depressed 1950s suburbanite opening Norman Vincent Peale's self-help book, The Power of Positive Thinking, would have encountered the following reassurance: "It is appalling to realize the number of pathetic people who are hampered and made miserable by the malady popularly called the inferiority complex. But you need not suffer from this trouble. When proper steps are taken, it can be overcome" (1). The comfort of this passage does not lie merely in Peale's promise that we can rid ourselves of insecurity, though it's a nice fantasy; the comfort lies in the suggestion that we are all looking for a cure for insecurity, that we are not alone in our misery. Better even than offering a solution, The Power of Positive Thinking validates dysfunction; it tells the reader: you are just like everyone else. But if it caters to the urge to feel normal, it simultaneously caters to the urge to feel unique; the two desires appear inseparable, mutually constitutive of each other. Peale's lament about the near universality of low self-esteem leads directly into the claim that you, the individual, can be different: "But you need not suffer from this trouble. When proper steps are taken, it can be overcome." "You" refers, of course, to "anyone." Peale's assertion is that anyone can rise above the problems that seem to plague everyone; it doesn't require exceptional qualities to be unique. But if it's not hard to be unique, if anyone can be unique, then that means the reader can be unique without relinquishing his averageness. Peale's promise satisfies both needs, to be unique and to be average, in a single paradoxical gesture.

Timothy Aubry is a Ph.D. candidate in the Department of English at Princeton University, where he is writing a dissertation devoted to the relationship between postwar U.S. fiction and middle-class selfhelp culture. 
Such contradictory messages both reflect and attempt to resolve tensions and anxieties prevalent in post-war American life. During the 1950s, the apparent expansion of corporations and the mass migration to the suburbs led to a pervasive fear that Americans had lost their individuality. Sociologist David Riesman famously asserted that people's values, once inner-directed, had become other-directed, and William $H$. Whyte observed that an emphasis on "belongingness" and getting along with others had replaced a previous emphasis on creativity, innovation, and cultivation of character. The term "conformity" appears with startling regularity in works by Spectorsky, Packard, Mills, Trilling, and others, and I find the ubiquity of the term more interesting than the supposed ubiquity of the phenomenon. ${ }^{1}$ Everyone, apparently, was worried about conformity, including the suburbanites Whyte interviewed for his study. ${ }^{2}$ Whether or not the tendency to conform was any more widespread than it had been in previous decades, and whether or not it was fostered by the corporation or the suburbs - both controversial questionsconformity became, during the 1950s, an explicitly articulated problem, as many Americans felt caught between a traditional paradigm that valued individualism and a social ethic that valued adjustment to a norm. This predicament was perceived as particularly dangerous for middle-class men, given that conventional notions of American masculinity tended to emphasize the importance of nonconformity.

The two major targets of concern-the corporation, which supposedly limited possibilities for entrepreneurship, and the suburb, which supposedly enforced strict codes of behavior and appearance - were rooted in American capitalism and the mass market. During the 1950 s many people feared that the American economic system, imagined to be the guarantor of individual liberty and free expression, was in fact suppressing individuality, producing a homogeneous population of passive, emasculated drones. According to Dwight Macdonald, for example, "[t]he tendency of modern industrial society, whether in the U.S.A. or the U.S.S.R., is to transform the individual into the mass man" (8). American capitalism, then, required an ideology that both defended the free market, along with the accompanying rise of the suburb, the corporation, and its techniques of mass marketing, and maintained faith in individual agency as a logical consequence and not a casualty of the free market. Self-help books, such as The Power of Positive Thinking, mass market products, which work, ironically, to alleviate anxieties generated by the mass market, answer a collective need for individuality through their personal address to the individual reader. Peale goes so far as to claim that he and the reader have formed a friendship: "We may never meet in person, but in this book we have met. We are spiritual friends" (224). Precisely the gesture that creates the illusion of intimacythe claim that the author has special knowledge of the reader's personal problems-demonstrates that the reader is no different from anyone else. By simultaneously gratifying the desire to be average and the desire to be unique, Peale's text works to resolve the contradiction between a market that apparently homogenizes the masses and a market that enables individuality. It tells readers-typically white male professionals: you can be an "average American," live in a suburban ranch house, buy the same commodities as everyone else, work in a corporation, and you can still be a unique individual. 


\title{
Suburban Readers
}

The central claim of this essay is that during the 1950s, serious fiction often performed the same functions and satisfied the same needs for its suburban readers as self-help texts. While authors such as Peale were assuring readers they could better themselves, distinguish themselves from their neighbors, publishers were offering serious literature as a means to do so. Before the 1940s the "classics" were owned and read primarily by wealthy individuals who could afford expensive hardcover and leather-bound books for their private libraries. In previous decades, publishing houses had attempted to sell paperback novels but had never been able to turn a profit. Robert de Graff, founder of Pocket Books, discovered the right formula: a combination of cuts in production costs and new marketing techniques. After his unprecedented success, he was joined by several other competing publishing companies, all of whom were printing classics and contemporary works of serious literature in cheap paperback form and marketing them to millions of Americans.

\section{Penguin editor Victor Weybright explains:}

\begin{abstract}
Reprints make universally available, for the first time in our history, the entertainment, information, instruction, and inspiration that formerly were available only to the well-to-do who could afford to pay from two dollars to ten dollars for a hard cover book and who had access to rather limited sources of book supply. They have performed a notable public service by turning into regular readers and hence better educated citizens countless millions who had little or no previous access to books. (qtd. in Davis 232)
\end{abstract}

Assuming Weybright's exuberantly democratic assessment is accurate, postwar paperback literature performed the function of self-help in two senses of the term. Firstly, many of these newcomers to serious literature had never been taught to obey modernist or highbrow interpretative protocols which would prohibit the assignment of a practical function to literature. Such untrained readers were, as Janice Radway has observed in her work on book club culture, more likely than the academic critic to treat serious fiction as a dispenser of practical advice, guidance, or therapy. ${ }^{3}$ Secondly, classics, printed in paperback form, extended to middle-class Americans the potential for self-education, self-improvement, and upward mobility, providing them with the cultural capital necessary to ascend class and social hierarchies. Both forms of self-help that paperback literature made available to the middle class-practical advice and cultural capital - led to uneasiness and frustration among intellectuals who did not like to see books treated as instruments. ${ }^{4}$ But there was little they could do; by the 1950s, middle-class Americans were participating in a rival literary culture consisting of magazines such as The New Yorker, book clubs, adult education classes, and radio and TV talk shows, a culture with its own set of priorities and protocols, which didn't always recognize the subtle distinctions between high and low art upheld by academics and serious critics, and which worried more about a book's practicality or relevance to readers' personal problems than about its objective aesthetic merit. ${ }^{5}$ 
John Cheever has often been denigrated by serious critics for catering to the needs of a suburban, middlebrow readership; Irving Howe, for instance, dismisses him as a "cautious therapist" (131). Cheever did believe, according to his son Benjamin, that "a fine piece of prose could not only cure a depression, it could clear up a sinus headache" (Cheever, Journals $\mathrm{x}$ ). His short stories, particularly those originally printed in The New Yorker and collected in The Housebreaker of Shady Hill and Other Stories, treat the usual suburban complaints: circumscribed agency, endangered masculinity, social exclusivity, and loss of traditional community. Published in 1958, the same year he won the National Book Award for The Wapshot Chronicle and saw his fame within the United States increase significantly, The Housebreaker of Shady Hill forever earned him his reputation as the suburban author. ${ }^{6}$ In this essay, I analyze the mechanisms for coping and the strategies for success and happiness that this text offers to readers, usually male readers, living within a corporate, suburban world. Cheever's approach means that he has not given up on suburbia altogether, and for this he has been the target of much critical ire. ${ }^{7}$ In my judgment, many of the attacks on Cheever are based upon a myopic view of suburbia as an unredeemable, homogeneous wasteland-a view which has been contested by several scholars, and which begs the very questions Cheever is in the process of working out in his stories. ${ }^{8}$ Moreover, to claim Cheever provides strategies for coping is not to say that he achieves no critical distance from suburbia; in fact, his project demands such a distance. If he is more optimistic and forgiving of his subjects than Riesman or Whyte, he is also more satirical and cynical than Norman Vincent Peale; one of the lessons to be learned from his fiction is that an effective strategy for suburban survival requires a complex synthesis of the sunny and the shrill. Thus his stories simultaneously employ and critique assumptions and concepts constitutive of positive-thinking, suburban self-help culture. Like Peale, Cheever valorizes the average individual, but, unlike Peale, he simultaneously problematizes this act of valorization.

\section{Suburban Exiles}

The narrator of the title story in The Housebreaker of Shady Hill, Johnny Hake, describes his life in the following way:

We have a nice house with a garden and a place outside for cooking meat, and on summer nights, sitting there with the kids and looking into the front of Christina's dress as she bends over to salt the steaks, or just gazing at the lights in Heaven, I am as thrilled as I am thrilled by more hardy and dangerous pursuits, and I guess this is what is meant by the pain and sweetness of life. (3)

One immediately wonders just how ironic is Hake, but the narrator's relationship to his language and his lifestyle is not constituted solely or primarily by irony; it's more like an all-too-comfortable marriage that one is intent on making work despite periodic misgivings. Hake is not entirely thrilled to find himself living a cliché, but he is dedicated to unearthing something poetic in the midst of his quotidian suburban experience, even if it turns out that this quixotic endeavor is itself 
a cliché. Aware of this possibility, he is hesitant to say simply, "I am experiencing the pain and sweetness of life," and instead uses the far more equivocal, "I guess this is what is meant by the pain and sweetness of life." It's not clear whether his uncertainty reflects a worry that his life is too prosaic to be called painful and sweet, or a worry that the phrase "the pain and sweetness of life" is too prosaic to encompass certain powerful moments in his life, but, in truth, it is unimportant whether it is the phrase or his life that he dislikes, for the two are inseparable. Both are clichés, and the question remains whether there is something poetic obscured by the cliché-stargazing when you forget to remember that you're "stargazing"or whether the poetry consists precisely in the cliché. Indeed, "the pain and sweetness of life" is a perfect phrase to describe his existence insofar as it is not entirely satisfying, yet still seems to reach beyond or perhaps within itself for something it can't entirely say.

Almost every character in Cheever's stories feels excluded from the state of contentment he believes, as an average suburbanite, he ought to be enjoying. The ubiquity of exclusion is significant; exclusion, after all, is the principle upon which many suburbs are founded. As one character notes, "So much energy is spent in perpetuating the place-in keeping out undesirables, and so forth-that the only idea of the future anyone has is just more and more commuting trains and more parties" (72). But suburbia doesn't just exclude those outside its boundaries; it also excludes everyone living within the suburb. ${ }^{9}$ All of Cheever's characters feel left out, sometimes literally excluded from a party or event, in other moments estranged from the suburban ideal they supposedly embody. Johnny Hake discovers that he has not been invited to a neighborhood softball game:

Why hadn't I been asked to play softball at the Toblers', I wondered. Why had we been excluded from these simple pleasures, this lighthearted gathering, the fading laughter and voices and slammed doors which seemed to gleam in the darkness as they were withdrawn from my possession. Why wasn't $I$ asked to play softball at the Toblers'? Why should social aggrandizement-climbing, really-exclude a nice guy like me from a softball game? What kind of world was that? (22)

Happiness, if it exists in the suburbs, is always happening somewhere else. Of course characters often want to be outsiders--they don't always want to think of themselves as suburbanites. Hake remarks, "Detesting this company, then, it was doubly painful for me to find myself in it" (23).

This position of insider/outsider is precisely the position that Cheever, or rather his narrative presence, occupies in the stories. Most of them are written in the third person, and much of the language is free indirect discourse, consisting of cheerful, banal expressions, such as "it was a pleasant garden" (55), "they would be the happiest married couple in the whole Eastern United States" (37), or "Will felt all right in the morning, and he had a good day in the city" (158). It is possible to read this language as a parody of the manner in which suburbanites talk and think, to imagine that the narrator is allowing the suburbanites to speak for themselves, while silently mocking their pretense of ease and happiness. But in several odd moments he asserts himself. For instance: "Cash sang, prayed, and got to his knees, but the 
most he ever felt in church was that he stood outside the realm of God's infinite mercy, and, to tell the truth, he no more believes in the Father, the Son, and the Holy Ghost than does my bull terrier"(45). Upon encountering such intrusions, we realize that the narrator is himself a character present in this world, another suburbanite like those he describes. His language can be read as parodic, but it is also his language. He must believe, to a certain extent, in the value of a pleasant garden, a happily married couple, or a good day in the city. Struggle as he might to get outside of Shady Hill, he is as much a part of it as anyone he ridicules. Given that the very essence of suburban experience is to be included/excluded, Cheever is in a difficult position as a satirist. To critique or mock suburbia, to feel or pretend to be outside suburbia, is the essence of what it means to be a suburbanite, so the more he jabs, the more he implicates himself as a part of the company he is critiquing. Cheever expresses his acute awareness of this predicament in a journal entry: "I was born into no true class, and it was my decision, early in life, to insinuate myself into the middle class, like a spy, so that I would have an advantageous position of attack, but I seem now and then to have forgotten my mission and to have taken my disguises too seriously" (Journals 16).

\section{Queer Masculinity}

For Cheever, the thrill of transgressing suburban conventions involves a flirtation with the queer. Johnny Hake has been stealing money from his neighbors, and he decides one night to return it, but, as he is doing so, the police catch him on his neighbor's lawn. "'I'm walking the dog,' I said cheerfully. There was no dog in sight, but they didn't look. 'Here, Toby! Here, Toby! Here, Toby! Good dog!' I called, and off I went, whistling merrily in the dark" (30). This moment represents both Hake's reconciliation with convention and his assertion of individuality; he recognizes that he can express his eccentricity while remaining within the normative, legal boundaries of suburban existence. Shady Hill is so invested in the appearance of normalcy that its residents and its police officers are literally unable to see exhibitions of aberration. The supposedly homogeneous mass culture promoted by post-war capitalism then does not necessarily function to undermine but can, if Cheever is right, actually facilitate individuality, creativity, and transgression. This was a lesson he may have learned through years of depicting homosexual desires in his fiction, without eliciting disapproval or even notice from most of his suburban readers. In 1974 Cheever revealed his ambivalent sexual inclinations to a graduate student, Dennis Coates, who was writing his dissertation on Cheever. Shortly afterwards, Coates remarked, amazed, "It's been in your work all along, hasn't it?" Cheever replied, “Of course it has. It's always been there, for all the world to see" (Donaldson, John Cheever 281).

Indeed, Hake's behavior at the end of the story could be called queer, a term that might be on the reader's mind, given Hake's earlier usage of it:

It seemed to me that if it had been my destiny to be a Russian ballet dancer, or to make art jewelry, or to paint Shuhplattler dancers on bureau drawers and landscapes on clamshells and live in some very low-tide place like Provincetown, I 
wouldn't have known a queerer bunch of men and women than I knew within the parablendeum industry, and I decided to strike out on my own. (6)

Hake's point is that one need not travel to an overtly transgressive community like Provincetown to encounter queerness; one can find it in the most ordinary settings, such as a plastics company or a conservative suburban community. Oppressive conventionality can indeed foster idiosyncrasy, but it also provokes a crisis for masculinity. The workplace, a realm which typically affirms a sense of traditional manhood, has become in this story a "queer" realm, producing for Hake a sense of ambivalent sexual identity.

During the 1950s there were serious concerns that the sphere of labor was no longer a secure source of masculine affirmation. Such anxieties were partially based upon a transition from an economy centered around production to an economy centered around consumption. ${ }^{10}$ In the postwar period, many more Americans were suddenly working in jobs that had nothing to do with producing goods and everything to do with selling them, with raw material that consisted not of physical things but people. Nonetheless, ingrained ideas that posited shaping and making material objects as the purpose of life persisted, leaving many workers with the uneasy sense that their jobs were pointless. And with an economy whose capacity to thrive and grow depended on continued consumption, Americans were subject to enormous pressure to spend their money; prodigality replaced thrift as a core value; shopping became a duty. If work suddenly felt as purposeless and desultory as leisure time, then leisure time suddenly felt as labored and goal-directed as work. The collapse of a clear distinction between work and leisure contributed to the male worker's sense of emasculation. The skills that were now the most important to cultivate - dealing with people, getting along with others - were those considered traditionally feminine. At the office, the executive worked only with ideas and symbols; and was thus deprived of the traditional means whereby he could assert his individual initiative and realize his masculinity. In short, he lacked a sphere that would distinguish him from his wife. ${ }^{11}$

In Cheever's story, one can understand Johnny Hake's departure from his job and his search for a mode of individual expression as a quest to recover his lost sense of masculinity. The ending, however, is ambiguous; walking an imaginary dog in the middle of the night is hardly an assertion of rugged manhood. In this story and others Cheever dramatizes a baffling predicament for the 1950s American male: popular mythology holds that the true man is a nonconformist, but the entrepreneurial age is past, and the work-world seems to offer fewer chances for individual initiative. He who wants to be a nonconformist, who wants to strike out on his own, must search for other contexts, other modes of action, and one hazard is that doing so may convict you of precisely the "queerness" you were trying to evade. Or, to put it differently, one of Cheever's insights is that in a homogeneous suburban community behaving "queerly" is one of the only means available to affirm one's masculinity.

In other stories, Cheever probes an unstable corporate, suburban masculinity even more explicitly. In "Just Tell Me Who It Was," Will is middle-aged, but married to a younger woman named Maria. He goes with her to a costume party dressed in 
knight's armor, only to be blinded by his visor and ignored by his wife as she dances with younger, more attractive men, and eventually has her tights "torn by the scales of a dragon." Will does not make a convincing chivalric hero or epic hero; ironic allusions to The Odyssey and "Cinderella," such as Maria's fantasy of her husband as a sailor returning from the sea and a pair of lost slippers, underscore his inadequacy. Will eventually initiates a skirmish with a rival suitor at a train station, but it is immediately broken up, and on the train Will imagines buying his wife a gift that his younger, more virile, but less wealthy competitor could never afford. Like Johnny Hake's whimsical performance, Will's plan seems an equivocal recuperation of a fragile masculinity at best.

No less equivocal is the decision by the protagonist in "The Country Husband," Francis Weed, to take up basement woodworking "as a therapy." In an article entitled "Do-it-Yourself: Constructing, Repairing, and Maintaining Domestic Masculinity," historian Steven Gelber writes, "If as numerous historians have asserted, industrialism and the rise of white-collar employment in sexually integrated work places made the job a more ambiguous source of masculine identity, then do-it-yourself provided men with an opportunity to recapture the pride that went along with doing a task from start to finish with one's hands" (68). Woodworking as a part of a "do-it-yourself" movement was a constitutive aspect of a self-help culture that attempted to affirm the average white-collar worker's belief in his power and masculinity. Some scholars, such as T. J. Jackson Lears, contend that this kind of activity is merely a therapeutic evasion, which provides a false sense of autonomy and reconciles individuals to a system that is stripping them of agency (47-58). Cheever's own position is more elusive. He pokes fun at Francis's hobby but does not dismiss it: "Francis finds some true consolation in the simple arithmetic involved and in the holy smell of new wood. Francis is happy" (82).

On the whole, Cheever is sympathetic to the rituals suburban men employ to affirm their sense of self; he does not believe such measures to be mere evasions, but recognizes them as important and complicated strategies for sustaining identity in an increasingly bewildering social world. At the end of "The Country Husband," just before declaring, "it is a night where kings in golden suits ride elephants over the mountains," he describes a cat wearing a dress "from the skirts of which protrudes its long hairy tail" (83). Here Cheever registers a sense that gender roles in Shady Hill have been mixed up, perhaps reversed, but this is not necessarily cause for despair. Aware of suburban manhood's contradictory, fragile character, of its reliance upon increasingly unstable supports, he paradoxically suggests that it may need to assimilate aspects, traits, and modes of expression from its supposed opposites - either queer or feminine - in order to insure its relevance and survival in the postwar period. This is not to say, of course, that Cheever wholeheartedly embraces alternative sexual identities. ${ }^{12}$ Misogyny and homophobia are in evidence everywhere in his journals and his fiction, and if he valorizes femininity and queerness, he does so only insofar as they can contribute to a more expansive, durable notion of masculinity - that is, only insofar as they are subject to patriarchal assimilation in the service of somewhat revised but still traditional gender politics. 


\section{Cheever and You}

Cheever's fiction does not merely describe a crisis of masculinity; it also functions to alleviate anxiety about emasculation among his male readers, as well as to provide strategies for success within a corporate, suburban world. Thus his fiction presupposes and addresses a reader who is a typical male suburbanite like the characters in his stories. Cheever's fiction claims to know you, to understand you, and inevitably requires you, the actual reader, to negotiate your relationship with the "you" that is constituted by the text.

In the title story, Johnny Hake speaks to us confidingly. Amid a series of statements that confirm his status as suburbanite he tells us, "[I] met my wife (Christina Lewis) at one of those big cotillions at the Waldorf" (3), assuming with "one of those" that the reader is familiar with the social world Hake inhabits. Hake assumes more: "The Warburtons are rich, but they don't mix; they may not even care. She is an aging mouse, and he is the kind of man that you wouldn't have liked at school. He has bad skin and a rasping voice and a fixed idea-lechery. The Warburtons are always spending money, and that's what you talk about with them" (7).

With his conversational tone and his direct address to the reader as "you," Hake establishes an intimacy between the narrator and reader. He assumes that the reader shares his tastes; he makes the reader feel special. He uses "you" a second time in this passage - "and that's what you talk about with them"- -but in this case the effect of "you" is not to establish intimacy. "You" is a stand-in for "one" or "anyone." The Warburtons are predictable: whoever is talking to them-you, Johnny Hake, or anyone else-will inevitably talk about money. Because the reader has just encountered what appeared to be a personal address, however, he is liable to construe this second "you" as directed to him, and thus, for a moment, experience a conflation of his individual identity with the general, impersonal category- "anyone." The second "you" complicates but does not undermine the intimacy created by the first "you." Together the two "you"s produce an ambiguous, liminal space, which the reader can occupy, a space which, like many self-help books, fulfills two opposed fantasies: that one is a unique individual, and that one is completely average, an everyman.

Cheever's two uses of "you" in this passage, then, exist in a tense relationship with each other, and this tension is due to their inseparability. The first "you" seems to single out the reader, constitute him as an individual, privileged to be the narrator's confidant. But if the narrator knows things about the reader it is only because the reader falls within a larger category, because the reader is typical. "He is the kind of man that you wouldn't have liked at school." The point here is that Warburton is the kind of man anyone would have disliked at school, or at least anyone within a particular social group. Hake has already discussed his own upper-class background-drilling as a child with the elite military youth group the Knickerbocker Greys (1), which counts Roosevelts and Vanderbilts amongst its graduates - and presumably Warburton's origins are of a similar character. In order to have been one of Warburton's classmates, the reader must, then, be white, 
male, and affluent. This much Hake assumes. It's not enough for him to conclude that the reader wouldn't have liked Warburton. Hake does, to a certain extent, individualize the reader, but he simultaneously categorizes the reader, constitutes him as generic. Moreover, the second "you" seems to refer to "anyone," but insofar as this passage specifically addresses the Warburtons' exclusivity - "they don't mix"-it's clear that not just anyone would be lucky enough to talk to them in the first place. The second "you," it turns out, is not at all general in its scope of reference. Being included in it is a privilege. Though it still places you in a category, it is a special, exclusive category, not evidence of your averageness. Both "you"s, owing to their elusive referentiality, allow the reader to feel at once special and generic, individual and ordinary, and the conjunction of the two only helps to illuminate the ambivalent character of each.

Cheever's ability to use "you" to refer simultaneously to the individual reader, to a limited sphere of suburbanites, and to "anyone," a readerly embodiment of common sense, is rooted in the white, male, suburban invasion and occupation of the category of the ordinary - an occupation that, in the $1950 \mathrm{~s}$, worked to reshape the ordinary to enclose suburban men and exclude everyone else. ${ }^{13}$ But in order to establish themselves as quintessentially ordinary people, suburban men need mechanisms that enable them to overlook both the work required to achieve the status of ordinary, and their exclusion of other groups. Cheever's prose style is a perfect instance of this self-deceiving, self-divided ideology; it is apparently democratic, yet in many ways quite exclusive. Even as Johnny Hake describes an inaccessible sphere of socialites, he renders himself accessible. His voice is urbane, but it is also unpretentious, inviting, approachable. His language is not demandingly allusive or obscure; it doesn't immediately exclude readers, but it does extend a sense of privilege to those who appreciate its understated wit.

Through its direct, second person modes of address, Cheever's fiction allows the reader to feel at moments individualized, and thus functions as a response to anxieties about the loss of individuality and the concomitant sense of emasculation in a corporate, mass-market society. At the same time, Cheever's fiction allows the reader to feel ordinary, safely within the category of conventional masculinity and hence not "queer." But, as a private activity, conducted within the safe boundaries of the domestic sphere, the act of reading is a problematic recuperation of masculinity, given masculinity's conventional connection to assertive, courageous activity in the wider social or material world. In fact, during the 1950 s reading fiction became increasingly connected to a feminine consumer culture owing to the sale of paperback romances in drug stores and marketing strategies such as the Book-ofthe-Month Club. Janice Radway observes:

What was initially troubling about the [Book-of-the-Month] club was not the character of the selections it mailed to its subscribers. Rather, what most disturbed the literary scene was the very nature of the club's distribution process and the way that process threatened to remake active, discriminating readers and writers into passive, feminized consumers, and effeminate poetasters. (Feeling for Books 204) 
A critic from the $1950 \mathrm{~s}$, Simon O. Lesser, remarks on the characterization of reading fiction as a feminine activity:

We tend to disparage the activity [of reading fiction], first of all, simply because it is so effortless. In some corner of cur minds exertion is associated with virtue and that which is easy with a kind of moral slackness .... In at least some men still another factor breeds distrust of anything which is easy: passivity is unconsciously equated with femininity and thus must be fiercely resisted. (4)

In light of such anxieties, Cheever's devices that gender his reader as male can be read as a reassurance, an assertion that it's perfectly normal to be male and to read fiction. Male white-collar workers must read fiction; otherwise, why would Cheever be addressing his stories to them? His text, then, functions both to affirm the male reader's sense of his own masculinity, and to reassure the reader that there is nothing unmanly about this very act of turning to fiction for affirmation.

Thus far I have described a reading experience that The Housebreaker of Shady Hill produces for those who actually fit within the intended audience. I realize, however, that this collection must have been read by many individuals who weren't well-educated, white, male suburbanites. I suspect that many such readers would experience varying degrees of alienation, while some would have found ways of imaginatively inhabiting the identity of the addressee constituted by the text, and therefore would potentially have responded in ways not altogether different from the intended audience. For instance, women are typically adept at automatically gendering themselves male when reading certain works of literature. ${ }^{14}$ And many other readers at the fringe of middle-class affluence - those hoping to move to suburbia, those who didn't quite fit into suburbia, or those who wanted to ascend higher in the suburban hierarchy - would have found Cheever's fiction immensely instructive, even when alienating. The challenge would be to imagine or constitute oneself as the intended reader. Learning to feel addressed by Cheever's fiction is a lesson in how to become a proper upper-middle-class suburbanite. Though this might sound like a repugnant task for fiction to perform, it does at least contribute, as a part of the paperback revolution, to the democratization of taste, to a wider dissemination of skills and attitudes previously monopolized by the established affluent class.

While Cheever typically caters to the needs of his niche audience, he is not always complicit with suburbanites' strategies of self-normalization. In "The FiveForty-Eight" he acknowledges suburbia's insular character and critiques its universalizing tendencies. Blake, a white-collar worker, thinks of himself as an average guy par excellence, a living embodiment of human nature, and at first Cheever seems to agree. Describing Blake's encounter with Miss Dent, a former mistress, Cheever writes, "[Blake] turned and walked toward the glass doors at the end of the lobby, feeling that faint guilt and bewilderment we experience when we by-pass some old friend or classmate who seems threadbare, or sick, or miserable in some other way" (115). Blake is representative, apparently, of everyone, and "we," according to Cheever, are all well-off enough to know what it feels like to pity some- 
one who is destitute. Later, recalling an argument with his wife, Blake reflects, "He had quarreled with his wife, but so did every man born of woman. It was human nature" (122).

Later in the story, however, Cheever subverts Blake's capacity to stand in for "human nature" by depicting his clash with Miss Dent, a relatively poor woman living outside the white middle-class world he inhabits. She confronts him during his commute home from work, and Cheever observes that "the slums and the city reminded Blake vaguely of the woman who had followed him" (123). Miss Dent represents a position of socio-economic marginalization that is both obscure and slightly alluring to Blake. Their relationship is also constituted by a faintly articulated racial dimension. "Her hair was dark, her eyes were dark; she left him with a pleasant impression of darkness" (118). Her darkness stands in total opposition to Blake's own paleness: "He was a slender man with brown hair-undistinguished in every way, unless you could have divined in his pallor or his gray eyes his unpleasant tastes" (120). Miss Dent's darkness suggests foreignness, and through her Blake enacts his desire to make contact with class and race identities other than his ownto add, as it were, a little color to his pallid existence.

At the end of the story, Miss Dent gives Blake a fleeting chance not only to make contact with the other, but to become the other. She pulls out a gun and pushes him to the ground. "He fell forward in the filth. The coal skinned his face" (134). As Blake falls, he immerses himself in the stuff of the working classcoal-and he puts on blackface, a connotation underscored by the use of the word "skinned," which means, in this case, to cover with a new skin. Blake becomes for an instant black and working-class, and he is feminized by Miss Dent's phallic gun. In this moment, one might conclude, he achieves the universality, the humanity, he desires for himself, by assuming multiple identities, by occupying, symbolically, the race, class, and gender positions ordinarily excluded by his privileged sphere. Ironically, the narrator earlier attributes Blake's universality not to a plurality but instead to a lack of distinguishing characteristics, a lack of color- "He was . . . undistinguished in every way" - as if he were truly colorless, as if being a white suburban male constituted the basic norm of humanity and not just a particular identity that acquires meaning only in relation to others. But Blake's attraction to Miss Dent demonstrates the need for those in his position to make contact with marginalized groups in order to affirm their positivity, their ascendancy, and their ability to confer upon themselves a universal status. At the end of the story, Cheever undermines Blake's power, even in his moment of mortification, to represent humanity. The crisis ends quickly; Miss Dent lets him go, the blackface turns out to be a transient stage-act, and Cheever ends the story in a perfunctory manner: "He got to his feet and picked up his hat from the ground where it had fallen and walked home" (134). Blake returns to his suburban life, having learned, it seems, nothing. The momentary degradation is less a chance for him to embody humanity than it is a subtle reminder to the reader of the various class, race, and cultural boundaries that prevent Blake or any character from adopting such a role. 


\section{How to Be Properly Miserable}

Like many of Cheever's characters, Blake unconsciously seeks a small dose of misery to mitigate the monotony of his suburban routines. This, Cheever seems to think, is a common desire, shared by his readers, and many of his stories strive to deliver the requisite pain. "The Worm in the Apple" is a perfect example. It opens with the following sentence: "The Crutchmans were so very, very happy and so temperate in all their habits and so pleased with everything that came their way that one was bound to suspect a worm in their rosy apple and that the extraordinary rosiness of the fruit was only meant to conceal the gravity and the depth of the infection" (107). The sentence, read carefully, sounds like a contradiction: the Crutchmans were so happy that one necessarily believed they were unhappy. My suspicion, and presumably Cheever's, is that most readers will fail to notice the contradiction at first and will automatically substitute "seemed so very, very happy" for "were so very, very happy." To put it slightly differently, it is almost impossible to hear the statement "The Crutchmans were so very, very happy" as a straightforward report of the facts; it is almost impossible to hear the statement without assuming it is ironic. Cheever, then, is setting before us our own way of hearing, our own cynical assumptions, and he is also parodying them. His pervasive irony, in other words, does not just apply to the first part of the sentence, but also to the second: "one was bound to suspect a worm in their rosy apple." Cheever is certainly questioning the Crutchmans' happiness, but he's also questioning the skeptical attitude that would question the Crutchmans' happiness. ${ }^{15} \mathrm{He}$ 's teaching us a lesson about our own knee-jerk pessimism, and, if we register his mockery, we are forced to accept the possibility that the Crutchmans are indeed happy. That is, after all, what the first line of the story categorically asserts. This realization would be potentially redemptive if we were not also forced to confront our own cynicismand not just our own cynicism, but everyone's cynicism. The game this sentence plays only works given the assumption that most readers will identify with "one" and doubt the happiness of the Crutchmans, only to have their own jaded attitude mocked. Sadly, the reader is forced to accept that 1) it's ridiculous to assume that anyone who seems really happy must be unhappy; 2) there might actually be really happy people in the world; 3 ) nevertheless he, the reader, is unhappy enough to doubt anyone else's appearance of happiness; and 4) if Cheever's suspicions are correct, everyone else who reads the story is unhappy enough to doubt anyone else's appearance of happiness. In short, if the Crutchmans are happy, they are the only ones. The consolation, like the consolation of most self-help books, is the reminder that we are not alone in our misery, and, as it turns out, even the Crutchmans have had their share of difficulties.

The lesson of this story is how to cultivate the correct attitude toward one's suburban existence. In subjecting the reader's cynicism to satire, Cheever is not preaching positive thinking; rather, he's teaching us how to be properly disaffected. We're allowed to be miserable, but we'll be better off-we'll be a bit less miserable, and we'll fit better into suburbia - if we moderate our dissatisfaction with some salutary self-irony. How to Be Properly Miserable: it's not an auspicious self-help 
title, but many would claim that this is exactly what self-help books, despite their unrealistic promises, actually teach readers. "The Worm in the Apple" confirms the reader's sense that cynicism is the norm, the correct attitude, and suggests that if you're not cynical there must be something wrong with you, while simultaneously mocking you for feeling cynical, thus creating further possibilities for self-loathing. Cynicism, admittedly, is not the same thing as misery, but one can cause the other, and Cheever has his share of both to bequeath. Most of the stories in Housebreaker dwell upon the unhappy aspects of suburban existence. Though it's certainly not the only possible response, it is quite easy to finish a Cheever story and find oneself profoundly depressed.

Given that I am attempting to establish Cheever's fiction as a form of selfhelp, one might rightly ask: is there anything useful about the unhappiness Cheever shares with the reader? Is there any help to be found in the misery he dispenses? Why would suburban readers want to increase their potential for discontent and self-pity? Catherine Jurca asks the same question: "It is worth considering how and why white middle-class self-representations have come to be associated with such excesses of self-pity, as though this population is prostrated by privilege" (18). Jurca's answer is that suffering is ennobling. She refers to suburbanites' "empowering rhetorics of victimization, which somehow only seldom manage to be anything but rhetorical" (19). Joel Pfister corroborates her view:

Members of the twentieth-century middle and upper classes, having adopted psychological and therapeutic discourses (which had nineteenth-century literary and domestic origins), affirmed their social superiority or potency by elevating the cultural value of anxiety, sexual conflicts, and familial tensions. Put differently, an increasing number of persons who belonged to these classes resignified anxiety as affirmation, emotional turmoil as subjective potency, and familial ambivalence as psychological capital. (40)

Both Jurca and Pfister posit the constitution of psychological dysfunction as a selfvalorizing device, as a solution to the banality and predictability that can result from affluence. Inner turmoil supplies a sense of meaning to fill the vacuum that emerges when the external demands of survival disappear.

Cheever is well aware that depression, dissatisfaction, and disorder can be exciting, can serve as sources of entertainment and meaning. Many characters in his stories create emotional upheaval on a regular basis, in a ritualistic fashion, in order to enliven their existence. Typically, a husband or wife will invite the threat of divorce as an elaborate form of foreplay; the couple will have a series of angry arguments, one will threaten to leave the other, and finally when it seems as if they really are going to break apart, they will end up in bed together, their love and passion rejuvenated by their near collapse. The pattern that structures Cheever's stories is one of deviation and return, difficulty and resolution. He underscores the repetitiveness of this pattern in the story "O Youth and Beauty!" by narrating portions of it in an imperfect tense, thus suggesting the tense imperfection that constitutes the grammar of his characters' lives: "[When they quarreled] Louise would run upstairs, throw herself onto the bed and sob. Cash would grab the 
whiskey bottle and dose himself .... The next night things would get worse" (36), etc. "But," Cheever notes, "these quarrels and reunions ... didn't seem to lose their interest through repetition" (38).

In "The Sorrows of Gin," Mr. Lawton retrieves his runaway daughter from the neighborhood train station:

The girl sitting on the bench, the rich names on her paper suitcase, touched him as it was in her power to touch him only when she seemed helpless or when she was very sick. Someone had walked over his grave! He shivered with longing, he felt his skin coarsen as when, driving home late and alone, a shower of leaves on the wind crossed the beam of his headlights, liberating him for a second at the most from the literal symbols of his life-the buttonless shirts, the vouchers and bank statements, the order blanks, and the empty glasses. He seemed to listen-God knows for what. Commands, drums, the crackle of signal fires, the music of the glockenspiel-how sweet it sounds on the Alpine air-singing from a tavern in the pass, the honking of wild swans; he seemed to smell the salt air in the churches of Venice. Then, as it was with the leaves, the power of her figure to trouble him was ended; his gooseflesh vanished. (104)

The moment is epiphanic but also fraught with pain. Lawton finds liberation in longing. He imagines himself inhabiting conventional masculine roles, he pictures himself a hero, in an army, obeying war drums; he gets goose bumps. This is what it means, according to Cheever, to be "troubled." No doubt Cheever also hopes that this passage will trouble his readers-will allow them to experience a disturbance, a pang of longing, which will briefly liberate them from the everyday and pain them just enough to imagine themselves heroes.

Emotional trouble, then, is a gift. But it is also a luxury, and as a luxury it is linked to affluence. Certain forms of depression and dysfunction are signifiers of prosperity, or, as Pfister calls them, "psychological capital." It's an old cliché that the wealthier you are the likelier you are to feel depressed and unfulfilled, but, according to Jurca, the causality works in both directions: "It is not just that professional and financial success cause misery, but that the misery that comes from disliking one's work propagates success" (141). Not being happy with one's position in the company propels one to promotion. Whyte makes a similar claim: the worker who is the most sensitive to the complex power dynamics in the corporation, most aware of how he is being manipulated, is the one who will be the most insecure, the most dissatisfied, but also the most powerful, the most capable of manipulating others and getting what he wants (167). Jurca puts it succinctly: "No dissatisfaction, the example of Greentree Avenue suggests, no mobility" (146).

Furthermore, mobility in the post-war period often meant geographic mobility. Because corporations generally had branches all across the country, the most successful workers tended to be moved around frequently. To climb the hierarchy, Whyte and Jurca maintain, the white-collar worker and his family had to be prepared for perpetual displacement. One female suburbanite, interviewed by Whyte, referred to herself as always "unsettled," suggesting a state of both geographic and emotional instability, and a link between the two conditions (298). Apparently, 
constant migration led many suburbanites to feel not only unstable but also detached, or at least led them to aspire to detachment. Whyte remarks: "The usual organization man tends to affect an attitude of fond detachment-swell place, lots of kicks, but, after all, the sort of place you graduate from" (304).

To succeed-and to be ready for what success would bring - the postwar suburbanite had to be capable of adapting rapidly to new contexts and communities. He had to moderate his idiosyncrasies and be like everyone else, while simultaneously cultivating detachment, even dissatisfaction, adopting an outsider's perspective that would prevent him from being rooted too long in one position or place, and would thus guarantee his continued mobility. To do all of this required that one cultivate a particular tone. Here Cheever becomes relevant and, indeed, useful. His insider/outsider, urbanely ironic, unsettled and unsettling attitude toward suburbia contains many of the ingredients necessary for both success and emotional survival. The complex, ambivalent stance that Cheever imparts to the reader can be considered self-help in two senses of the term: his fiction provides both counsel for coping with emotional turmoil and practical strategies for ascending class and culture hierarchies. If, as Jurca and Whyte contend, dissatisfaction is a condition for success, Cheever's fiction teaches us precisely how to be dissatisfied. It provides us with a model of well-managed misery conducive to economic and social success, as well as relative emotional stability-without excluding redemptive moments of catharsis.

The final story in Housebreaker, "The Trouble of Marcie Flint," opens with an indictment of suburbia interrupted by a rebuttal:

"This is being written aboard the S. S. Augustus, three days at sea. My suitcase is full of peanut butter, and I am a fugitive from the suburbs of all large cities. What holes! The suburbs, I mean. God preserve me from the camaraderie of commuting trains, and even from the lovely ladies taking in their asters and their roses at dusk lest the frost kill them, and from ladies with their heads whirling with civic zeal. I'm off to Torino, where the girls love peanut butter and the world is a man's castle and ..." There was absolutely nothing wrong with the suburb (Shady Hill) from which Charles Flint was fleeing, his age is immaterial, and he was no stranger to Torino, having been there for three months recently on business. (165)

As in "The Worm in the Apple," Cheever has a lesson ready for the reader lest he identify too quickly with the voice of hysterical cynicism. Charles Flint's attack on suburbia and his hopes for escape are quickly undermined, or at least tempered by the narrator. But having once tripped, the reader might be too cautious to join the opposing camp immediately. Presented with this petulant dialectic, all one can do is feel uneasy. Both sides, though compellingly comedic, are a bit shrill, and one hopes in vain that Cheever will step in and adjudicate the conflict. He remains inscrutable behind these warring poses; he does, however, provide each as a curb on the other's vision. The story offers less a resolution of the debate than a healthy synthesis of the two perspectives.

In the title story, Cheever attempts to effect this synthesis in a single voice. On the subject of suburbia, Johnny Hake comments: 
Shady Hill is, as I say, a banlieue and open to criticism by city planners, adventurers, and lyric poets, but if you work in the city and have children to raise, I can't think of a better place. My neighbors are rich, it is true, but riches in this case mean leisure, and they use their time wisely. They travel around the world, listen to good music, and given a choice of paper books at an airport, will pick Thucydides, and sometimes Aquinas. Urged to build bomb shelters, they plant trees and roses, and their gardens are splendid and bright. (12)

Hake has, by this point, already proven himself to be a wit, capable of deadpan satire, and so the reader can, if he wants, easily hear this passage as ironic. Moreover, Hake registers an awareness that his apparently laudatory depiction of suburbia is controversial, susceptible to attack. It would be easy to laugh at the absurdity of provincial suburbanites reading airport copies of Thucydides for the sake of self-improvement-in fact, so easy that the more challenging and sophisticated response might be, oddly enough, to take the passage at face value and not locate any irony or ulterior subtext. George W. Hunt argues that Cheever's fiction employs irony in order to transcend it, dialectically, so as to move from negation to affirmation: "Almost every story begins with the wry perspective of irony-i.e., the detached, often sardonic viewpoint of an outside observer - but as the story develops, this ironic perspective imperceptibly vanishes, and by the story's end an entirely different focus, that of compassionate understanding, has taken its place" (17). Hunt's analysis says more about what he wants out of Cheever (or what he wants out of life) than it does about Cheever's fiction - which I read as ultimately too conflicted and self-undermining to be interpreted so optimistically. Nevertheless, I think it is crucial that it is possible to read Cheever in the way Hunt does, that it is possible to read Johnny Hake's endorsement of suburbia as sincere. But it is also crucial that it is possible to read Hake's praise as ironic.

Hake's attitude, after all, is not merely sardonic or celebratory; neither would be an effective strategy for suburban survival. His attitude is more complex. The clever, carefully modulated, tonally ambiguous voice that Johnny Hake has cultivated accomplishes several seemingly irreconcilable tasks. It allows him to speak praisingly of his community when he wants, in a convincing enough manner to facilitate his own integration. But it also allows him, even in the moment of praising Shady Hill, to preserve the possibility of ironic detachment, a trait which would make him all the more popular in a community like Shady Hill, while allowing him some purchase on autonomy. Because his tone is not entirely jaded and detached, because it also retains the possibility of sincerity, it allows him moments of earnest emotion and childlike appreciation of his everyday world that cannot be construed as either entirely naîve or entirely artificial. Lastly, it enables him to maintain some degree of individuality under and within the guise of convention, so that even when his behavior or his language is cliché, one suspects he is appropriating the cliché for his own idiosyncratic purposes. Johnny Hake can function as a model for the reader; the demands he places on one's interpretative capacities are instructive. Learning how to hear his tone is a way of learning how to develop one's own tone, how to develop an attitude and an identity potentially more sophisticated, mature, and healthy than one dominated by naïve self-satisfaction or facile irony. Though 
the pose offered by Cheever entails self-division and internal strife, it represents perhaps the only hope for enjoying suburbia while simultaneously maintaining one's distance, one's mobility, and one's capacity for critique.

\section{Notes}

' See Spectorsky; Packard; Mills; Trilling.

${ }^{2}$ Whyte writes:

Now this may be conformity but it is not unwitting conformity. The people know all about it. When I first started interviewing on this particular aspect of suburbia, I was at first hesitant; it is not very flattering to imply to somebody that they do what they do because of the environment rather than their own free will. I soon found out, however, they not only knew quite well what I was interested in but were quite ready to talk about it. Give a suburban housewife a map of the area, and she is likely to show herself a very shrewd social analyst. After a few remarks about what a bunch of cows we all are, she will cheerfully explain how funny it is she doesn't pal around with the Clarks any more because she is using the new supermarket now and doesn't stop by Eleanor Clark's for coffee like she used to. (331)

${ }^{3}$ Radway writes: "The BOMC editors believe, finally, that their readers purchase serious fiction because they value verbal facility but also, and perhaps more important, because they are seeking a model for contemporary living and even practical advice about appropriate behavior in a changing world" ("Book-of-the-Month-Club" 535).

${ }^{4}$ Radway writes:

Concomitantly, criticism served the constitutive function of determining the very boundary of the literary. "Literature" evolved, then, as an honorific term to be conferred by experts only on those works that rendered themselves distinct from the quotidian, the mundane, and the profane. As such, literary books resisted any instrumentalist approach to their contents. They were to be valued in and for themselves alone. Literature was not to be crudely "used"; it was to be appreciated. (Feeling for Books 141)

${ }^{5}$ For a reading of these developments, see Rubin; Ross.

${ }^{6}$ According to Scott Donaldson, "[w]ith the publication of The Housebreaker of Shady Hill and Other Stories in September 1958, [Cheever] became known, overnight and always, as a chronicler of suburban life" (John Cheever 179). Though Housebreaker was never a bestseller, it contains, according to Michael D. Byrne, "Cheever's most widely anthologized stories" (8), and many readers who didn't buy the collection encountered the stories in The New Yorker.

${ }^{7}$ See Howe; Gilman.

${ }^{8}$ See Donaldson, The Suburban Myth; May; Foreman.

${ }^{9}$ Whyte explores internal exclusion within the suburb of Forest Hills, attempting to trace the imaginary boundaries and fault lines which organize and partition both the physical and social space of the suburb: "Ambiguity is the one thing the group cannot abide. If there is no line, the group will invent one. They may settle on an imaginary line along the long axis of the court, or, in the homes area, one particular house as the watershed" (348).

${ }^{10}$ For an explanation of this development, see Galbraith.

"1 This worry is expressed by Riesman, Whyte, Mills, and Spectorsky, among others. Whyte writes: "We have, in sum, a man who is so completely involved in his work that he cannot distinguish between work and the rest of his life" (150). 
${ }^{12}$ Lawrence Jay Dessner, in fact, argues that Cheever's fiction affirms traditional gender inequalities.

${ }^{13}$ For a discussion of the middle class's efforts to occlude other classes and universalize based on its own experience, see Ehrenreich.

${ }^{14}$ Judith Fetterly writes:

Though one of the most persistent of literary stereotypes is the castrating bitch, the cultural reality is not the emasculation of men by women but the immasculation of women by men. As readers and teachers and scholars, women are taught to think as men, to identify with a male point of view, and to accept as normal and legitimate a male system of values, one of whose central principles is misogyny. (xx)

${ }^{15}$ George W. Hunt makes a similar observation about the narrator's cynical, failed search for a worm: "But alas, our indefatigable investigator ferrets out no such worm, and the result is irony turned in on itself, a twist that ironizes the ironist, thereby giving birth to humor" (18).

\section{Works Cited}

Byrne, Michael D. Dragons and Martinis: The Skewed Realism of John Cheever. San Bernadino, CA: Borgo Press, 1993.

Cheever, John. The Housebreaker of Shady Hill and Other Stories. New York: Harper \& Brothers, 1958.

-. The Journals of John Cheever. New York: Alfred A. Knopf, 1991.

Davis, Kenneth C. Two-Bit Culture: The Paperbacking of America. Boston: Houghton Mifflin, 1984.

Dessner, Lawerence Jay. "Gender and Structure in John Cheever's 'The Country Husband." Short Fiction 31 (1994): 57-68.

Donaldson, Scott. John Cheever: A Biography. New York: Random House, 1988.

-. The Suburban Myth. New York: Columbia University Press, 1969.

Ehrenreich, Barbara. Fear of Falling: The Inner Life of the Middle Class. New York: Pantheon, 1989.

Fetterly, Judith. The Resisting Reader: A Feminist Approach to American Fiction. Bloomington, IN: Indiana University Press, 1978.

Foreman, Joel. Introduction. The Other Fifties: Interrogating Midcentury American Icons. Ed. Foreman. Chicago: University of Illinois Press, 1997. 1-23.

Galbraith, John Kenneth. The Affluent Society. 2nd ed. Boston: Houghton Mifflin, 1969.

Gelber, Steven M. "Do-it-Yourself: Constructing, Repairing and Maintaining Domestic Masculinity." American Quarterly 49 (1997): 66-112.

Gilman, Richard. "Dante of Suburbia." Commonweal 69 (1958): 320.

Howe, Irving. "Realities and Fictions." Partisan Review 26 (1959): 131.

Hunt, George W. John Cheever: The Hobgoblin Company of Love. Grand Rapids, MI: William B. Eerdman, 1983.

Jurca, Catherine. White Diaspora: The Suburb and the Twentieth-Century American Novel. Princeton, NJ: Princeton University Press, 2001.

Lears, T. J. Jackson. No Place of Grace: Antimodernism and the Transformation of American Culture 1880-1920. New York: Pantheon, 1981.

Lesser, Simon O. Fiction and the Unconscious. Boston: Beacon Hill Press, 1957.

Macdonald, Dwight. Against the American Grain. New York: Random House, 1962.

May, Larry, ed. Recasting America: Culture and Politics in the Age of Cold War. Chicago: University of Chicago Press, 1988. 
Mills, C. Wright. White Collar: The American Middle Classes. New York: Oxford University Press, 1951.

Packard, Vance. The Hidden Persuaders. New York: D. McKay Co., 1957.

Peale, Norman Vincent. The Power of Positive Thinking. New York: Prentice-Hall, 1952.

Pfister, Joel. "On Conceptualizing the Cultural History of Emotional and Psychological Life in America." Inventing the Psychological. Ed. Pfister and Nancy Schnog. New Haven, CT: Yale University Press, 1997. 17-59.

Radway, Janice. "The Book-of-The-Month-Club and the General Reader: On Uses of 'Serious' Fiction." Critical Inquiry 14 (1988): 516-538.

- A Feeling for Books: The Book-of-the-Month Club, Literary Taste, and Middle-Class Desire. Chapel Hill, NC: University of North Carolina Press, 1997.

Riesman, David. Lonely Crowd: A Study of the Changing American Character. New Haven, CT: Yale University Press, 1950.

Ross, Andrew. No Respect: Intellectuals and Popular Culture. New York: Routledge, 1989.

Rubin, Joan Shelley. The Making of Middlebrow Culture. Chapel Hill, NC: University of North Carolina Press, 1992.

Spectorsky, A. C. The Exurbanites. Philadelphia, PA: Lippincott, 1955.

Trilling, Lionel. Freud and the Crisis of our Culture. Boston: Beacon Press, 1955.

Whyte, William H. The Organization Man. New York: Simon \& Schuster, 1956. 